\title{
The creation of a low-capacity boiler plant on coal-enrichment waste
}

\author{
Murko V.I. \\ Mining institute \\ FSBEI HE “KuzSTU” \\ Kemerovo, Russia \\ sib_eco@mail.ru
}

\author{
Baranova M.P., \\ Institute of engineering systems and power \\ industry \\ FSBEI HE "Krasnoyarsk SAU" \\ Krasnoyarsk, Russia
}

\author{
Khyamyalyainen V.A. \\ Mining institute \\ FSBEI HE "KuzSTU” \\ Kemerovo, Russia
}

\begin{abstract}
A serious problem for coal production is the environmentally friendly utilization of coal mining waste and coal enrichment. In different countries, the best specialists in this field are trying to find the solution of this problem. In the United States, France and China, the technology of preparation and burning of water-coal suspensions (WCS) for the utilization of fine-dispersed wastes of coal enrichment and coal slurries has been successfully used. A boiler with a thermal capacity of 0.63 MW with a vortex combustion system efficiently operating on fuel from coal waste was designed, manufactured and tested. The results of the operation of the boiler on this fuel showed its high efficiency (the efficiency is $\mathbf{8 3 - 8 6 \% )}$ ) with the level of harmful emissions in the flue gases below the permissible values
\end{abstract}

Keywords-ash-and-slag wastes, fine waste of coal enrichment, a boiler with a vortex combustion system

\section{INTRODUCTION}

A serious problem for coal production is the utilization of coal mining waste and coal enrichment. At present, around each large mine, surface mine or coal-processing plant, "tails" are formed - huge stores of wet or liquid waste. Such coal waste is called coal slurry. The medium-sized coal-processing plant produces from 300 to 600 tons of slurry daily - the same "tails" that are stored in numerous sludge pits or rock dumps [1-3]. The use of carbonaceous wastes is economically advantageous for many enterprises and, especially in coal mining areas, but under the condition of efficient combustion. Coal-containing waste in coal mining regions has a negative cost (storage and landfill maintenance costs) [4]. At present, practically all-Russian coal-preparation plants have their own boiler plants for heat supply and hot water supply. Boilers installed in boiler plants are usually equipped with combustion furnaces with layer combustion of coal. The efficiency of these boilers is from 50 to $70 \%$, which is due to high mechanical and chemical underburn. In addition, boilers with layered furnaces are not designed to burn enrichment products such as industrial products, coking coals and fine coal slurries, for example, filter cake [5-10].
The most effective, in this case, way of burning high-ash waste of coal enrichment is burning in the form of water-coal fuel suspensions. In the USA, France and China, the technology of preparation and burning of water-coal suspensions (WCS) for the use of fine-dispersed waste coal and coal slurries in power engineering is successfully used. This fuel has its own characteristics, which must be taken into account when creating a heat generator working on such fuel. For economical, environmentally cleaner burning of coal and involvement of low-grade ballasted fuels and waste in the fuel balance of enterprises, it is necessary to develop scientific foundations for organizing highly efficient combustion technologies and accumulating practical experience in their operation. The aim of the work was to create a heat generator of small and medium power, which could work on high-ash waste of coal-enrichment.

\section{RAW MATERIALS AND METHODS OF WCS PREPARATION}

For the preparation of suspension water-coal fuel, representative samples of fine-dispersed waste of coal enrichment (FDWCE) - filter cakes from the filtration departments of the CPP the mine "Komsomolets" (LeninskKuznetsky city, Kemerovo region) were used. The characteristic of the FDWCE is presented in Table 1.

TABLE I. QUALITATIVE CHARACTERISTIC OF THE FILTER CAKE

\begin{tabular}{|l|c|}
\hline Indicator name & Numeric value \\
\hline Moisture, general, $\mathrm{W}_{\mathrm{t}}{ }_{\mathrm{r}}, \%$ & 34,8 \\
\hline Ash content (dry condition of fuel), $\mathrm{A}^{\mathrm{d}}, \%$ & 26,8 \\
\hline $\begin{array}{l}\text { The yield of volatile substances (on the dry } \\
\text { ashless state of the fuel), } \mathrm{V}^{\text {daf }}, \%\end{array}$ & 43,1 \\
\hline Sulfur common (dry fuel), $\mathrm{S}_{\mathrm{t}}{ }^{\mathrm{d}}, \%$ & 0,48 \\
\hline $\begin{array}{l}\text { The highest heat of combustion (on a dry } \\
\text { condition of fuel), } \mathrm{Q}_{\mathrm{s}}{ }^{\text {daf }}, \mathrm{MJ} / \mathrm{kg}\end{array}$ & 33,04 \\
\hline
\end{tabular}




\begin{tabular}{|c|c|}
\hline $\begin{array}{l}\text { The lowest heat of combustion of the } \\
\text { working fuel, } \mathrm{Q}_{\mathrm{t}}{ }^{\mathrm{r}}, \mathrm{MJ}\end{array}$ & 14,3 \\
\hline Granulometric composition, mm,\% & \\
\hline $0,250-3,0$ & 8,4 \\
\hline $0,071-0,250$ & \\
\hline$-0,071$ & 12 \\
\hline Total & 100,0 \\
\hline
\end{tabular}

Evaluation of the preparation possibility of water-coal fuel from coal-washing wastes and selection of the optimal plasticizing additive were carried out under laboratory conditions on a universal shaker stand.

During the studies, samples of suspension coal fuel in an IED grinding chamber were prepared from a mixture of filter cake and an aqueous solution of the plasticizer reagent. The amount of water and the content of the plasticizer in it were determined by calculation, depending on the quality of the starting product. The obtained samples of WCS were analyzed for the mass fraction of the solid phase, the particle size distribution, viscosity and stability. The mass fraction of the solid phase was determined by the standard drying method in accordance with GOST 27314-91, the granulometric composition by wet sieving in accordance with GOST 209382. The lowest heat of combustion was determined by calculation in accordance with GOST 27313-87.

On the basis of the laboratory tests, the most effective plasticizer was determined, the consumption of which was $0.25 \%$ of the solid phase in the fuel.

\section{PReparation of WCS PILOT LOTS BASED ON THE FDWCE}

Experimental lots of WCS based on the FDWCE were prepared at the coal preparation section of the experimental stand. Figure 1 shows the technological scheme for the WCS preparation.

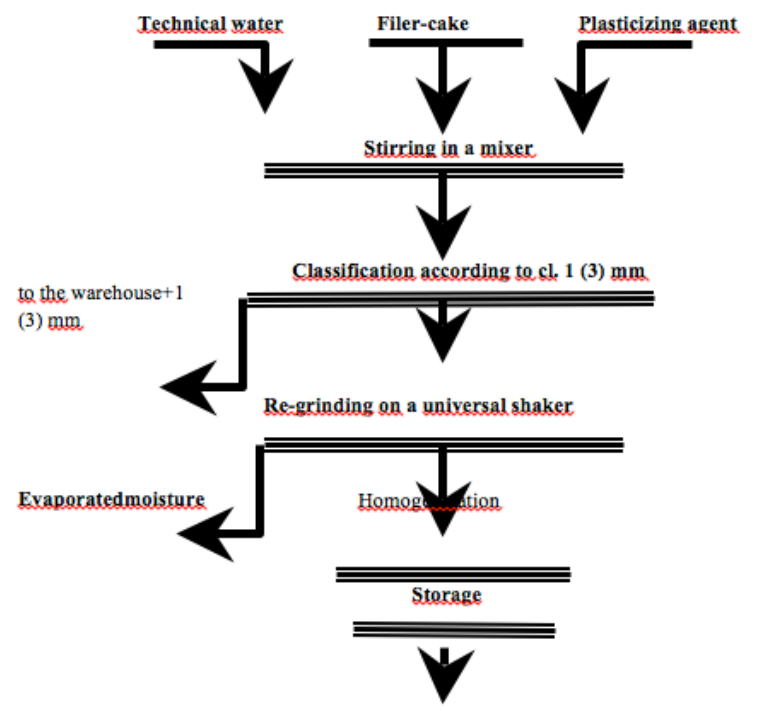

According to the flow chart, the initial filter cake and the aqueous solution of the plasticizer reagent were fed into a batch mixer, then the resulting water-coal suspension was dosed to a universal shaker, where there was further grinding and further mixing of the obtained fuel. The prepared WCS was pumped into storage tanks. Table 2 shows the structuralrheological and thermophysical parameters of the WCS.

LOTS OF WCS

TABLE II. CHARACTERISTICS OF THE PREPARED PILOT

\begin{tabular}{|c|c|c|c|c|c|}
\hline $\begin{array}{l}\text { Ash } \\
A^{d}, \\
\%\end{array}$ & $\begin{array}{c}\text { Class } \\
\text { output is } \\
\text { more } \\
0,25 \mathrm{~mm}, \\
\%\end{array}$ & $\begin{array}{l}\text { Mass } \\
\text { fraction of } \\
\text { solid } \\
\text { phase, } C_{\mathrm{T}} \text {, } \\
\%\end{array}$ & $\begin{array}{c}\text { Effective } \\
\text { viscosity at } \\
\text { shear rate } \\
81 \mathrm{~s}^{-1}, \eta, \\
\mathrm{mPa} \cdot \mathrm{s}\end{array}$ & $\begin{array}{c}\text { Stabil } \\
\text { ity, } \\
\text { day }\end{array}$ & 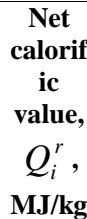 \\
\hline 26,8 & 1,9 & 56,9 & 178 & 15 & 12,22 \\
\hline
\end{tabular}

It was experimentally established that the productivity of a universal plant for the initial suspension varies in the range $0.155 \mathrm{t} / \mathrm{h}-0.217 \mathrm{t} / \mathrm{h}$, depending on the particle size in the initial suspension. In this mode of operation, the output of the class $+0.250 \mathrm{~mm}$ in the finished suspension did not exceed the limit $(\mathrm{R} 250 \leq 5 \%)$ required by the combustion conditions and was $1.4 \%-1.9 \%$.

\section{WCS BURNING AT THE EXPERIMENTAL STAND}

The boiler (see Figure 2) consists of a vertical cylindrical body 1 with a water-cooled jacket 2, a door 3 and a lid 4, a grate 5 and an ash pan 6 . The outer surface of the cylindrical body is thermally insulated. Burner devices 7 with nozzles (not shown in the figure) and slit nozzles 8 for tangential supply of blast air are mounted on the side surface of the casing. The inner cylindrical surface of the combustion chamber above the grate is thermally insulated with heatresistant material 9. For connecting and discharging the heattransfer fluid, the pipes 10 and 11, respectively, are installed. For heat removal, a heat exchange system 12 is provided between the hot combustion products and the heat carrier. The boiler body and the heat exchange system are connected by the flue 13. The boiler body with the ash pan and the heat exchange system are mounted on the frame 14 .

Initially, the internal cavity of the boiler body is heated the combustion chamber placed above the grate, by burning solid fuel on the grate. Subsequently, the supply of a suspension water-coal fuel begins [11, 12].

Fig. 1. Flow chart of WCS preparation from the filter cake 

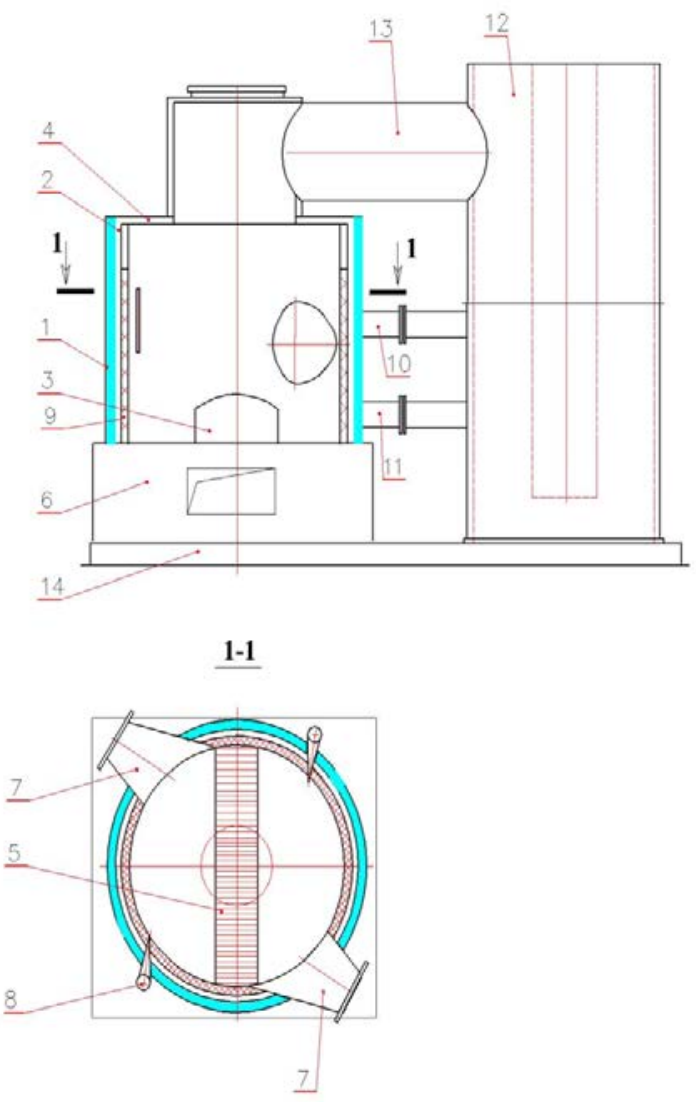

b.

Fig. 2. Construction of the boiler.

Suspended coal-water fuel is supplied to the boiler by a pump from the storage tank through the nozzles of the burner devices 7. The spraying compressor air is also supplied to the nozzles. Sprays of atomized fuel are supplied tangentially to the conventional surface inside the combustion chamber of the boiler body 1 . At the same time, tangentially into the combustion chamber air is supplied through the slotted nozzles 8 oriented in the same direction as the burners. Due to the organization of vortex motion in the boiler body, effective combustion of the atomized fuel is carried out [13]. Possible unburned coarse coal particles fall on the grate 5, where they burn out, creating an additional "lighting" in the combustion zone of the atomized fuel. Large particles of ash and slag deposits accumulated on the grate are periodically unloaded into the ash pan 6 . The hot gases generated by the combustion of the fuel through the internal cavity of the boiler lid 4 and the flue 13 enter the heat exchange system 12 . As a result, heat exchange takes place between the hot gases and the heat transfer fluid. Partial heat exchange between the combustion products and the heat transfer fluid also occurs in the boiler body due to the presence of a water-cooled jacket 2 . Reliable and efficient operation of the boiler is also ensured by the presence of adiabatic or close to them conditions in the combustion zone of the fuel [14].

Transportation of flue gases from the furnace to the economizer is provided by a smoke exhaust fan. After the economizer, the flue gases enter a two-stage dust collector, and then they are thrown into the atmosphere through a chimney [15].

Figure 3 shows the WCS from the filter cake, the appearance of the heat generator and the burning process of the fuel.

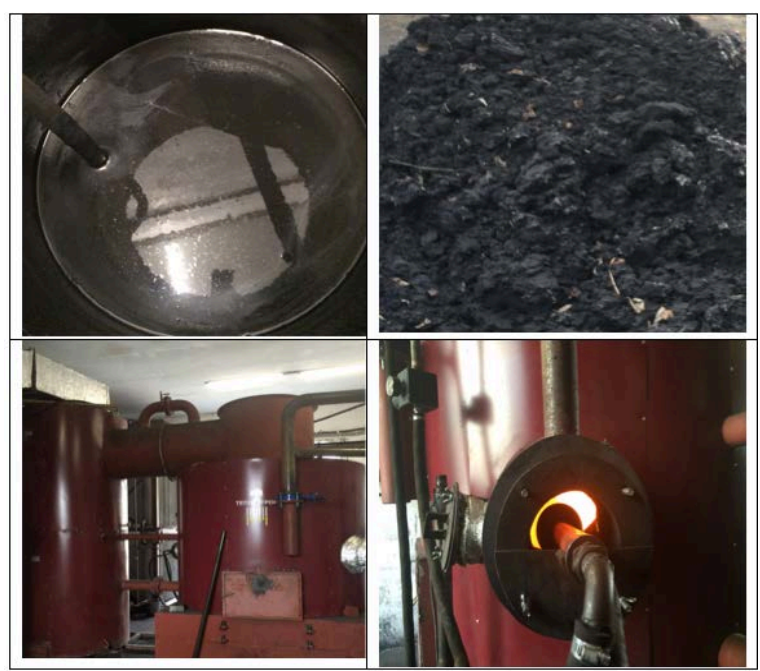

Fig. 3. WCS from the filter cake and the burning process of the fuel.

TABLE III. TEST RESULTS

\begin{tabular}{|l|c|c|}
\hline \multicolumn{1}{|c|}{ The name of indicators } & $\begin{array}{c}\text { Under the } \\
\text { project }\end{array}$ & $\begin{array}{c}\text { Actually } \\
\text { achieved }\end{array}$ \\
\hline $\begin{array}{l}\text { Heating capacity of the boiler, } \\
\text { MW }\end{array}$ & 0,63 & 0,65 \\
\hline $\begin{array}{l}\text { The lowest heat of combustion of } \\
\text { fuel, kcal / kg }\end{array}$ & $3000-3100$ & $2600 \div 3400$ \\
\hline Fuel consumption, $\mathrm{l} / \mathrm{h}$ & 300 & $160 \div 370$ \\
\hline Temperature in the furnace, ${ }^{\circ} \mathrm{C}$ & $1050 \pm 50$ & $1100 \pm 100$ \\
\hline Flue gas temperature,${ }^{\circ} \mathrm{C}$ & 180 & 180 \\
\hline $\begin{array}{l}\text { Water temperature },{ }^{\circ} \mathrm{C}: \\
\text { - at the entrance } \\
- \text { at the exit }\end{array}$ & $\begin{array}{l}60 \\
80\end{array}$ \\
\hline Efficiency of boiler,$\%$ & 0,85 & 85 \\
\hline
\end{tabular}

During testing of the experimental setup, the fuel consumption, taking into account the change in the net calorific value of WCS, varied from $205 \mathrm{~kg} / \mathrm{h}$ to $370 \mathrm{~kg} / \mathrm{h}$. The temperature in the furnace was $1000-1100^{\circ} \mathrm{C}$.

The composition and amount of harmful emissions from combustion of fuel samples prepared on the basis of fine coal waste from the coal mine "Komsomolets" showed that the obtained values of harmful emissions are significantly lower than the allowable values for coal boilers of this power when using high-ash fuel (dust, $\mathrm{mg} / \mathrm{m}^{3}$ - not more than 170 , $\mathrm{CO}, \mathrm{mg} / \mathrm{m}^{3}$ - not more than 75; NOx, $\mathrm{mg} / \mathrm{m}^{3}$ - not more than 250; $\mathrm{SO}_{2}, \mathrm{mg} / \mathrm{m}^{3}$ - no more than 200, at specifications: 
dust - $250 \mathrm{mg} / \mathrm{m}^{3}$, CO - $375 \mathrm{mg} / \mathrm{m}^{3}$, NOx $-750 \mathrm{mg} / \mathrm{m}_{3}$, $\mathrm{SO}_{2}-1200 \mathrm{mg} / \mathrm{m}^{3}$ ).

\section{CONCLUSIONS}

(1) As a result of the work performed, a boiler with a thermal capacity of $0.63 \mathrm{MW}$ with a vortex combustion system efficiently operating on fuel from coal waste was developed, manufactured and tested. The results of the boiler operation on this fuel showed its high efficiency (the efficiency is 83-86\%) with the level of harmful emissions in the flue gas significantly below the permissible values.

(2) The technology and equipment for the preparation and combustion of small and medium-power slurry water-coal fuel, obtained from fine-dispersed coal cleaning waste (filter cakes) from the mine "Komsomolets" coal-preparation plant were developed. It is shown that on the basis of these wastes it is possible to prepare a suspension water-coal fuel with a solid phase content of $56-60 \%$, with the required structuralrheological characteristics and a net calorific value of up to 13 $\mathrm{MJ} / \mathrm{kg}$.

\section{REFERENCES}

[1] Wan E.I., Fraser M.D., Logan C.N. Low sulphur coal-water fuel to retrofit a coal-fired to comply with US clean air act ammendments of 1990. In: Proceedings og yhe IEA-CLM. Clearwater, FL, USA, (26 April 1993) - Paris, France, International Energy, (1993). p 22

[2] Ashworth R.A., Melick T.A., Morrison D.K., Battista J.J. Electric utility CWS firing options to reduce $\mathrm{NO}_{\mathrm{x}}$ emissions, Twenty Third International Technical Conference on Coal Utilization \& Fuel Systems, Coal \& Slurry Technology Association and ASME-FACT, Clearwater, Florida (1998), -p. 719-730

[3] Morrison J.D., Scaroni A.W., Battista J.J. The use of coal slurries for production of coal-water fuel. XIII International Coal Preparation Congress. Brisbane, Australia (4-10 Oct. 1998). -p. 643-645
[4] Alaa M. Musalam and Abdel Fattah A. Qaraman. The thermal behavior of the coal-water fuel (CWF). International Journal of Energy and Environmental Research, Vol. 4, No.3, (August 2016). pp.27-36

[5] Murko V.I., Karpenok V.I., Senchurova Yu.A., Khyamyalyainen V.A., Tailakov O.V. Study of sulfur oxide reduction during combustion of coal-water slurry. Coal in the 21st Century: Mining, Processing and Safety (2016). pp. 297-300.

[6] Murko V.I., Fedyaev V.I., Karpenok V.I., Zasypkin I.M., Senchurova Y.A., Riesterer A. Investigation of the spraying mechanism and combustion of the suspended coal fuel. Thermal Science. (2015). T. 19. № 1. pp. 243-251

[7] Murko V.I., Puzyryov E.M., Karpenok V.I., Fedyaev V.I. Baranova M.P. The Usage Of Boilers With A Vortex Furnace For Burning Enrichment Products And Deballasting Coal. XVIII International Coal Preparation Congress 28 June-01 July 2016 Saint-Petersburg, Russia

[8] I. M. Zasypkin. Systems of ignition and combustion stabilization for water-coal fuel. Thermal science Vol. 16, No. 4, (2012). pp. 1229-1238

[9] Murko V.I., Fedyaev V.I., Aynetdinov H.L., Baranova M.P. Environmentally Clean Technology of Fine Waste Coal Utilization. XVII International coal preparation congress, Istanbul, Turkey (1-6 Oct. 2013)

[10] Patent No. 2145038. M.cl. F 23 Q 5/00. Method of Combustion and Combustion Stabilization of the Water-Coal Fuel in the Settling Chamber (in Russian), V. I. Murko, M. P. Fomicheva, A. N. Timoshevskiy, I. M. Zasypkin, et al. - No. 97120914/06. Appl. 03.12.97. Published on 27.01.2000, Bulletin No. 3

[11] Prudhon M.G. Boiler plant with a circulating liquid phase of 320 MWth, France unification project collieries SODELIF. Helsinki, Finlande (1013 May 1993)

[12] Biletskyy V., Sergeyev P. and Krut O. Fundamentals of highly loaded coal-water slurries. Mining of Mineral Deposits. Taylor \& Francis Group, London (2013). pp. 105-113

[13] Mochalov S. P., Rybenko I. A., Ermakova L. A. Mechanism and Mathematical Modeling of Coal-Water Slurry Combustion in Swirl Adiabatic Combustion Chamber. World Applied Sciences Journal 19 (1) (2012). pp. 20-25

[14] Kijo-Kleczkowska, A., 2011. Analysis of cyclic combustion of the coalwater suspension Archives of Thermodynamics, 32(1). pp. 45-75

[15] Kijo-Kleczkowska, A. Combustion of coal-water suspensions, Fuel, 90 (2011) 2, pp. 865- 